\title{
Effects of Photoperiod Manipulation on Gonadal Activity of the Damselfish, Chromis notata
}

\author{
Chi-Hoon Lee, Young-Ju Park and ${ }^{\dagger}$ Young-Don Lee \\ Marine Science Institute, Jeju National University, Jeju 63333, Korea
}

\begin{abstract}
This study investigated the effect of different photoperiods (14L: 10D, 12L:12D and 10L:14D) on the gonadal development and GtH mRNA expression in the pituitary of damselfish. The results showed that gonadosomatic index (GSI) was significantly lower in shot photoperiod (10L:14D), in comparison with other photoperiodic group during the spawning season. After 60 days treatment, histological analysis of gonad tissue showed that the gonad of 10L:14D and 12L: 12D treatment groups were resting phase with spermatogonia and perinucleolus stage oocytes but the gonad of 14L:10D treatment group was still ripe phase with spermatozoa and mature stage oocyte. The FSH $\beta$ and LH $\beta$ mRNA expression in pituitary drastically decreased shot photoperiod treatment from July (spawning period). These results suggest that photoperiod is considered to be the most effective environmental factor in controlling the reproductive cycle of damselfish.
\end{abstract}

Key words : Photoperiod, Gonadal development, FSH $\beta$, LH $\beta$, Damselfish, Chromis notata

\section{INTRODUCTION}

Most fishes have a distinct spawning season and their annual spawning cycle is influenced by various environmental factors, especially photoperiod and water temperature (Biswas et al., 2004; Suquet et al., 2005). These environmental factors affect the Brain-Pituitary-Gonad (BPG) axis, and induce gonadal development and spawning through regulation by neuropeptide and sexual hormone in reproductive endocrine system (Shimizu, 2003; Howell et al., 2003; Levy et al., 2011; Shao et al., 2013). There are many studies of the influences of reproductive activity in fish, particularly the effects of photoperiod and water temperature on gonadal development.

Damselfish, Chromis notata is widely distributed in tro- pical and temperate waters and one of the important fishery species in Korea. The spawning of damselfish $C$. notata inhabiting Jeju Island, Korea occurred from June to August (Lee \& Lee, 1987). In the temperate fish, photoperiod is the main proximal factor in the timing of gonadal maturation. Photoperiod alternations are used to stimulate or delay gonadal development (Falcon et al, 2003; Sarkar \& Upadhyay, 2011). However, it is unclear whether damselfish utilize these environmental factors for initiation and termination of their reproductive activity. Therefore, the present study investigated the effects of photoperiod on gonadal activity of the damselfish in Jeju Island, South Korea. In addition, RT-PCR assays mRNA expression of GtH subunits (FSH $\beta, \mathrm{LH} \beta)$ in the pituitary gland under the artificial condition where photoperiod is controlled.

\footnotetext{
Manuscript received June 7 2017, Received in revised form June 12, 2017, Accepted June 13, 2017

$\dagger$ Corresponding Author : Young-Don Lee, Marine Science Institute, Jeju National University, Jeju 63333, Korea. Tel: +82-64-782-8922, Fax: +82-64782-8281, E-mail: leemri@jejunu.ac.kr

This is an Open Access article distributed under the terms of the Creative Commons Attribution Non-Commercial License (http:// creativecommons.org/licenses/by-nc/3.0) which permits unrestricted non-commercial use, distribution, and reproduction in any medium, provided the original work is properly cited.
} 


\section{MATERIALS AND METHOD}

\section{Fish}

Sexually mature male and female damselfish Chromis notata (standard length 7.0 to $9.0 \mathrm{~cm}$, body weight 12.0 to $30.0 \mathrm{~g}$ ) were collected in coastal waters of the Bomok, Seogwipo, Jeju, South Korea. Adult animals were kept at the Marine Science Institute, Jeju National University, Jeju, South Korea, in 1.5 ton aquaria with an open seawater circulation system. The experimental fish were divided into three groups; 14L:10D, 12L: 12D and 10L:14D. They were reared for approximately 60 days from June to August 2011. Ten to fifteen fish from each group were randomly selected to compare gonadal development and GtHs expression under different conditions. The experimental fish were anesthetized with 2-phenoxyethanol (Sigma-Aldrich, St. Louis, Mo), then hypothalamus, pituitary and ovary were extracted. The extracted ovary of each specimen were weighted for calculation of the gonadosomatic index (GSI=gonad weight/body weight $\times 100$ ). For the histological analysis, ovaries samples were fixed in Bouin's solution, embedded in paraffin, sectioned $5 \mu \mathrm{m}$ thickness and stained with haematoxylin-eosin. The hypothalamus and pituitary sample were kept at $-80^{\circ} \mathrm{C}$ until total RNA extraction.

\section{Total RNA extraction and cDNA synthesis}

The total amount of RNA from the hypothalamus and pituitary samples was extracted using RNAiso Reagent (TaKaRa Bio, Kyoto, Japan). The total RNA was treated with RQ RNase-free DNase (Promega, Madison, WI, USA) to prevent genomic DNA contamination. The hypothalamus and purity of the total extracted RNA from the pituitary was examined with the ratio of 1.7 and 2.1 for A260/A280. From $1 \mu \mathrm{g}$ of the extracted total RNA, the reverse transcription reaction was performed to synthesize cDNA using the Transcriptor First strand cDNA Synthesis kit (Roche Diagnostics, Mannheim, Germany).

\section{Real-time qPCR (qPCR)}

Primers for the experiments were produced by $\operatorname{FSH} \beta$ and LH $\beta$ of damselfish $C$. notata that are listed on NCBI. A qPCR was conducted with $20 \mathrm{ng}$ of cDNA using SYBR green premix PCR kit (Takara) in CFX96 ${ }^{\mathrm{TM}}$ Real-time System (Bio-Rad, Hercules, CA, USA). PCR was performed at $95^{\circ} \mathrm{C}$ after the initial denaturation. Afterwards, the PCR reaction was performed by 40 cycle of denaturation for $45 \mathrm{~s}$ at $94^{\circ} \mathrm{C}$, annealing for $45 \mathrm{~s}$ at $58^{\circ} \mathrm{C}$, and extension for 1 min at $72^{\circ} \mathrm{C}$. Expression of the FSH $\beta$ and $\mathrm{LH} \beta$ genes in each sample was normalized to the amount of the internal control $\beta$-actin gene.

\section{Statistical analysis}

All data are presented as mean \pm standard error (SEM) and considered significantly different at $P<0.05$. Statistical analysis of data was analyzed by one-way ANOVA followed by Duncan's multiple range test using statistics 18.0 for windows (SPSS Inc.).

\section{RESULTS AND DISCUSSION}

In $30^{\text {th }}$ June 2011, the GSI of male and female in initial group was $1.43 \pm 0.65$ and $2.44 \pm 1.05$ respectively. However, in $30^{\text {th }}$ July 2011, GSI of 10L:14D treatment group showed drastically decreased at $0.39 \pm 0.29$ of male and $2.40 \pm 2.25$ of female, showing a significant statistical difference $(P<0.05)$. And in $30^{\text {th }}$ August 2011, GSI of 12L:10D treatment group also showed drastically decreased at $0.56 \pm 0.38$ of male and $0.60 \pm 0.05$ of female but GSI of 14L:10D treatment group showed high levels at $2.46 \pm$ 1.19 of male and $5.72 \pm 1.02$ of female (Fig. 1).

In $30^{\text {th }}$ June 2011, the testis of initial group was mature phase, spermatozoa were filled in testicular lobules. After 30 days, the testis of 10L:14D treatment group was spent phase and observed undischarged sperm in the center of the testicular lobules but the other treatment group was 

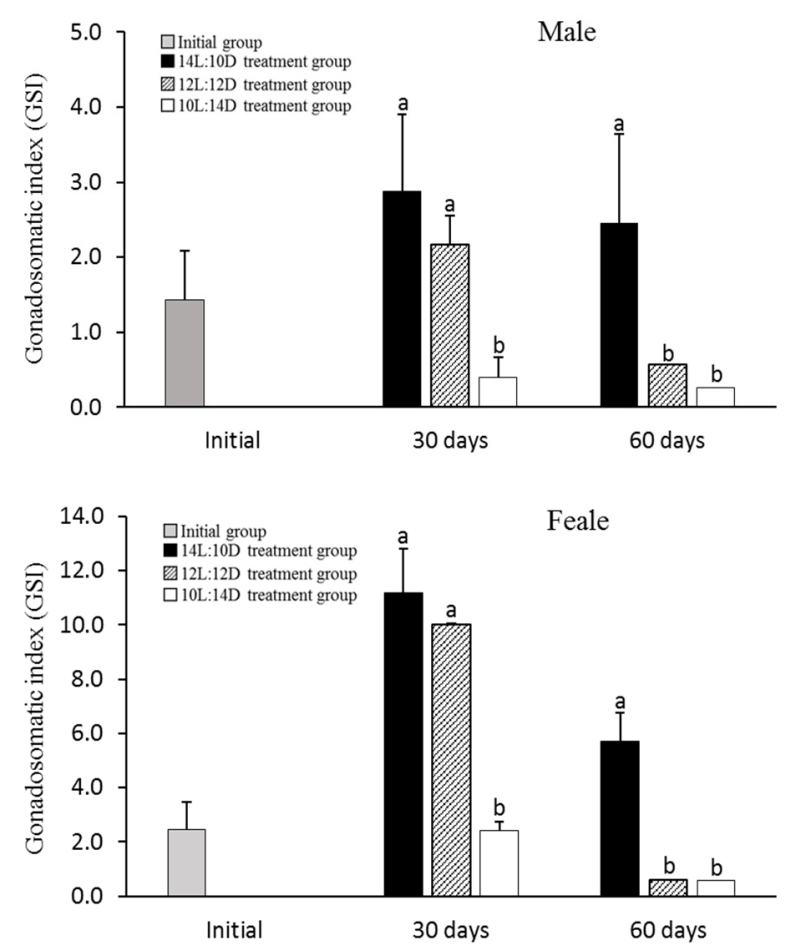

Fig. 1. Gonadosomatic index (GSI) in damselfish, Chromis notata under different photoperiod conditions. Means represented by different letters are significant $(P<0.05)$. Values are mean \pm SEM.

mature phase. After 60 days, the testis of 10L:14D and 12L: $12 \mathrm{D}$ treatment groups were resting phase with spermatogonia but the testis of 14L:10D treatment group was still ripe phase (Fig. 2). In $30^{\text {th }}$ June 2011, the ovary of initial group was mature phase with vitellogenic oocytes of 400 to $500 \mu \mathrm{m}$ in diameter. After 30 days, the ovary of $10 \mathrm{~L}$ : 14D treatment group was spawning phase and observed postovulatory follicle but the other treatment group was mature phase. After 60 days, the ovary of 10L:14D and 12L: $12 \mathrm{D}$ treatment groups showed early growing phase and contained mainly perinucleolus stage oocytes but the ovary of 14L:10D treatment group was still ripe phase, contained mature oocytes (Fig. 3).

In the $10 \mathrm{~L}: 14 \mathrm{D}$ treatment group of male, the expression levels of FSH $\beta$ and LH $\beta$ mRNA was significantly decreased at July and August 2011 than the other treatment group. However 14L:10D treatment group showed high levels

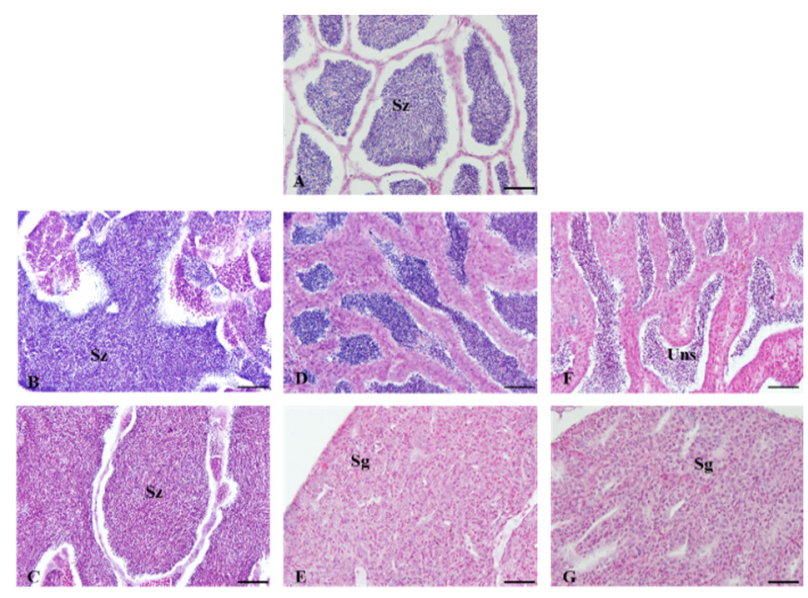

Fig. 2. Photomicrograph of testis development phases of damselfish, Chromis notata under different photoperiod conditions from June 2011 to August 2011. (A) initial testis of June 2011; (B-C) testis of July and August 2011 under 14L:10D condition; (D-E) testis of July and August 2011 under 12L:12D condition; (F-G) testis of July and August 2011 under 10L:14D condition. Sg, spermatogonia; Sz, sper-matozoa. Uns, undischarged sperm. Scale bars indicate $40 \mu \mathrm{m}$.

throughout all of the experiments (Fig. 4). Female GtH showed similar to male pattern. The expression levels of FSH $\beta$ and LH $\beta$ mRNA in the 10L:14D treatment group was significantly decreased at July and August 2011 (Fig. 5).

Spawning cycle and spawning timing of fish is determined by environmental conditions (photoperiod, water temperature and nutrient state etc.). Previous studies have shown effects of the environment, especially photoperiod and temperature, on sexual maturation and spawning, sexual maturation is regulated through the brain-pituitary-gonad (BPG) axis (Huber \& Bengtson, 1999; García-López et al., 2006; Migaud et al., 2010). In the Nile tilapia, Oreochromis niloticus L., gonadal development was suppressed by treatment of constant and long photoperiod ( $\operatorname{Rad}$ et al., 2006). In the sea bass Dicentrarchus labras, photoperiodic manipulation delayed maturation for three months with respect to controls (Zanuy et al., 1986). The Arctic charr, Salvelinus alpinus under decreasing photoperiod (16L:8D 

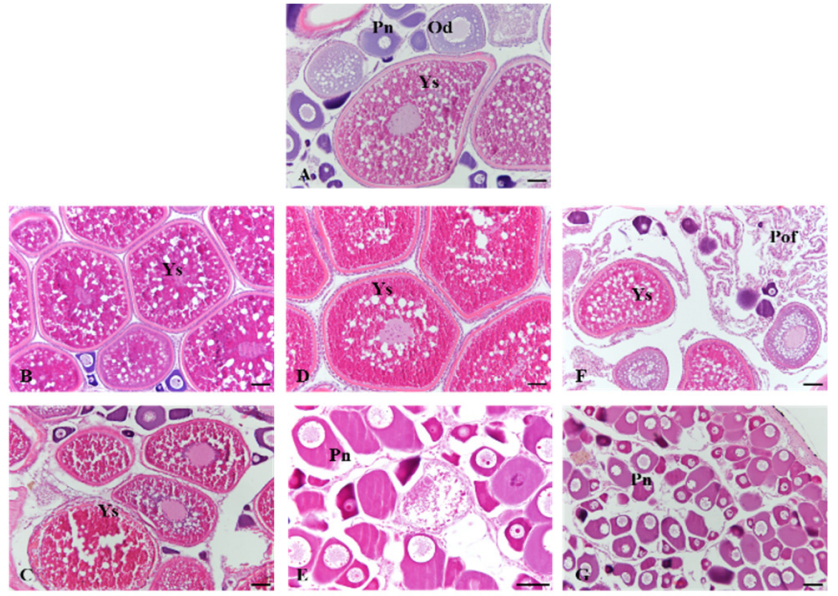

Fig. 3. Photomicrograph of ovarian development phases of damselfish, Chromis notata under different photoperiod conditions from June 2011 to August 2011. (A) initial ovary of June 2011; (B-C) ovary of July and August 2011 under 14L:10D condition; (D-E) ovary of July and August 2011 under 12L:12D condition; (F-G) ovary of July and August 2011 under 10L:14D condition. Pn, perinucleolus stage; Pof, postovulatory follicle; Od, oil-droplet stage; Ys, Yolk stage. Scale bars indicate $50 \mu \mathrm{m}$.

reducing to $8 \mathrm{~L}: 16 \mathrm{D}$ ) delaying the reproductive cycle (reduction of up to $66 \%$ on sexual maturation of males and $32 \%$ females) (Duston et al., 2003). The Atlantic cod (Gadus morhua) under the 24L:0D photoperiod significantly decreased expression of FSH $\beta$ and LH $\beta$ during the sex maturation period (de Almeida et al., 2011). Amano et al. (1995), testing the two different conditions of short photoperiod (8L:16D) and long photoperiod (16L:8D), a shot photoperiod treatment induced sex maturation but long photoperiod treatment delayed sex maturation. Olive flounder, Paralichthys olivaceus, a marine species that spawns in the spring, also showed low GSI and delayed sexual maturation when treated under long photoperiod of 15L:9D from September to March, until the spawning season. Also, FSH $\beta$ and LH $\beta$ mRNA expression in pituitary decreased more in long photoperiod treatment group than in natural photoperiod (Kim et al., 2013). In this study, shot photoperiod treatment from July (spawning period; mature stage)
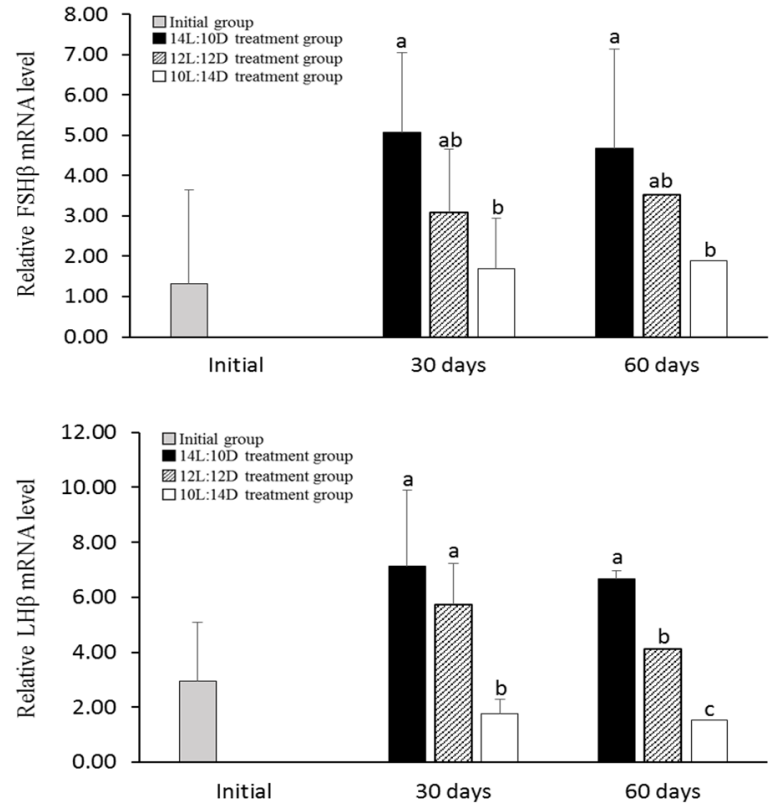

Fig. 4. FSH $\beta$ and LHß mRNA levels in the pituitary of male damselfish, Chromis notata under different photoperiod conditions. Means represented by different letters are significant $(P<0.05)$. Values are mean \pm SEM.
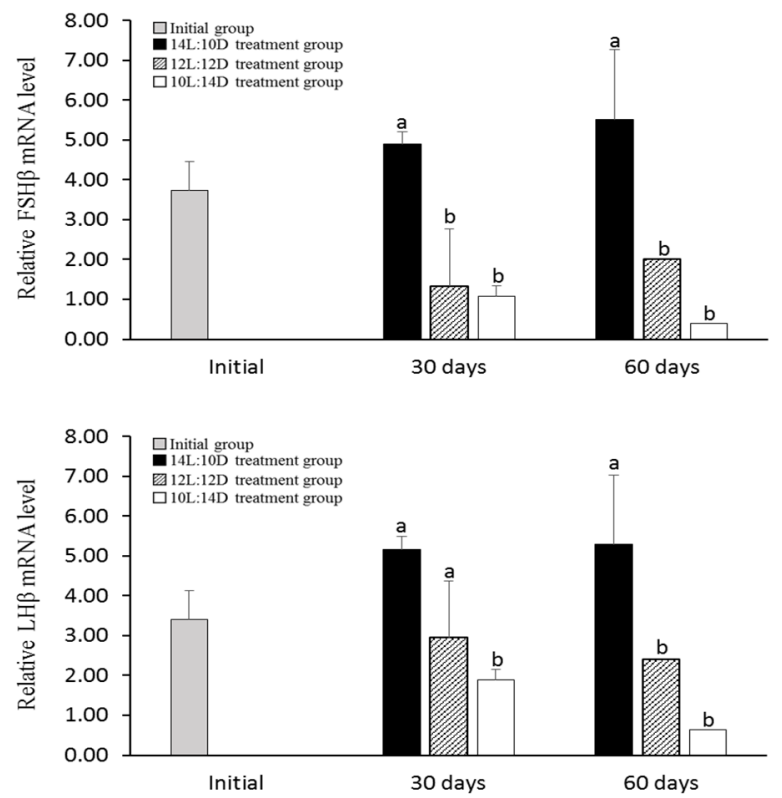

Fig. 5. FSH $\beta$ and LHß mRNA levels in the pituitary of female damselfish, Chromis notata under different photoperiod conditions. Means represented by different letters are significant $(P<0.05)$. Values are mean \pm SEM. 
was decreased gonadal development and reduced FSH $\beta$ and LH $\beta$ mRNA expression in pituitary of damselfish but long photoperiod treatment was maintained gonadal development and keeped FSH $\beta$ and LH $\beta$ mRNA expression in pituitary. These results show how the photoperiod affects the reproduction of several fish species, interfering with the control of gonadal maturation and pre-paration for reproduction. Photoperiod is considered to be the most effective environmental factor in controlling the reproductive cycle of damselfish.

\section{ACKNOWLEDGEMENT}

This research was supported by the 2016 scientific promotion program funded by Jeju National University.

\section{REFERENCES}

Amano M, Hyodo S, Kitamura S, Ikuta K, Suzuki Y, Urano A, Aida K (1995) Short photoperiod accelerates preoptic and ventral telencephalic salmon GnRH synthesis and precocious maturation in underyearling male masu salmon. Gen Com Endocrionol 99:22-27.

Biswas AK, Morita T, Yoshizaki G, Maita M, Takeuchi T (2005) Control of reproduction in Nile tilapia Oreochromis niloticus (L.) by photoperiod manipulation. Aquaculture 243: 229-239.

de Almeida FFL, Andersson E, Mittelholzer C, Karlsen Ø, Taranger GL, Schulz RW (2011) Pituitary gonadotropin and testicular gonadotropin receptor expression in atlantic cod (Gadus morhua L.) during the first reproductive season: Effects of photoperiod modulation. Gen Comp Endocrinol 173:111-119.

Duston J, Bromage N (1986) Photoperiodic mechanisms and rhythms of reproduction in the female rainbow trout. Fish Physiol Biochem 2: 35-51.

Duston J, Astatkie T, Macisaac PE (2003) Long-to-short photoperiod in winter halves the incidence of sexual maturity among Arctic charr. Aquaculture 221: 567580.

Falcon J, Besseau L, Fazzari J, Attia P, Galidrat M, Beauchaud M, Boeuf G (2003) Melatonin modulates secretion of growth hormone and prolactin by trout pituitary glands and cells in culture. Endocronology 144: 46484658.

García-López Á, Pascual E, Sarasquete C, Martínez-Rodríguez G (2006) Disruption of gonadal maturation in cultured Senegalese sole Solea senegalensis Kaup by continuous light and/or constant temperature regimes. Aquaculture 261:789-798.

Howell RA, Berlinsky DL, Bradley TM (2003) The effects of photoperiod manipulation on the reproduction of black sea bass, Centropristis striata. Aquaculture 218: 651-669.

Huber M, Bengtson DA (1999) Effects of photoperiod and temperature on the regulation of the onset of maturation in the estuarine fish Menidia beryllina (Cope) (Atherinidae). J Exp Mar Biol Exol 240:285-302.

Kim BH, Lee CH, Hur SW, Hur SP, Kim DH, Suh HL, Kim SY, Lee YD (2013) Long photoperiod affects gonadal development in olive flounder Paralichthys olivaceus. Dev Reprod 17: 241-246.

Lee YD, Lee TY (1987) Studies on the reproductive cycle of damselfish, Chromis notatus (Temminck et Schlegel). Bull Korean Fish Soc 20: 509-519.

Levy G, David D, Degani G (2011) Effect of environmental temperature on growth and reproduction-related hormones gene expression in the female blue gourami (Trichogaster trichopterus). Comp Biochem Physiol A 160:381-389.

Migaud H, Fontaine P, Kestemont P, Wang N, Brun-Bellut $J$ (2004) Influence of photoperiod on the onset of gonadogenesis in Eurasian perch Perca fluviatilis. Aquaculture 214: 561-574.

Shao YT, Arvidsson M, Trombley S, Schulz RW, Schmitz M, Borg B (2013) Androgen feedback effects on LH 
and FSH, and photoperiodic control of reproduction in male three-spined sticklebacks, Gasterosteus aculeatus, Gen Comp Endocrinol 182: 16-23.

Shimizu A (2003). Effect of photoperiod and temperature on gonadal activity and plasma steroid levels in a reared strain of the mummichog (Fundulus heteroclitus) during different phase of its annual reproductive cycle. Gen Comp Endocrinol 131: 310-324.
Suquet M, Normant Y, Gaignon JL, Quemener L, Fauvel C (2005) Effect of water temperature on individual reproductive activity of Pollack (Pollachius pollachius). Aquaculture 243: 113-120.

Zanuy S, Carrillo M, Ruiz F (1986) Delayed gametogenesis and spawning of sea bass (Dicentrarchus labrax L.) kept under different photoperiod and temperature regimes. Fish Physiol Biochem 2: 53-63. 